\title{
Selective adsorption of L1210 leukemia cells/human leukocytes on micropatterned surfaces prepared from polystyrene/polypropylene-polyethylene blends
}

\author{
Nevin Atalay Gengec ${ }^{\mathrm{a}}$, Hilal Unal Gulsuner ${ }^{\mathrm{b}}, \mathrm{H}$. Yildirim Erbil ${ }^{\mathrm{a}, *}$, Ayse Begum Tekinay $^{\mathrm{b}}$ \\ a Gebze Institute of Technology, Department of Chemical Engineering, 41400 Gebze, Kocaeli, Turkey \\ ${ }^{\mathrm{b}}$ Institute of Materials Science and Nanotechnology, National Nanotechnology Research Center (UNAM), Bilkent University, 06800 Ankara, Turkey
}

\section{A R T I C L E I N F O}

\section{Article history:}

Received 27 June 2013

Received in revised form 21 August 2013

Accepted 18 September 2013

Available online 26 September 2013

\section{Keywords:}

Micropatterning

L1210 leukemia cells

Leukocytes

Selective cell adhesion

Contact angle

\begin{abstract}
A B S T R A C T
The objective of this study is to prepare polymeric surfaces which will adsorb L1210 leukemia cells selectively more than that of healthy human leukocytes in order to develop new treatment options for people with leukemia. Chemically heterogeneous and micropatterned surfaces were formed on round glass slides by dip coating with accompanying phase-separation process where only commercial polymers were used. Surface properties were determined by using optical microscopy, 3D profilometry, SEM and measuring contact angles. Polymer, solvent/nonsolvent types, blend composition and temperature were found to be effective in controlling the dimensions of surface microislands. MTT tests were applied for cell viability performance of these surfaces. Polystyrene/polyethylene-polypropylene blend surfaces were found to show considerable positive selectivity to L1210 leukemia cells where L1210/healthy leukocytes adsorption ratio approached to 9-fold in vitro. Effects of wettability, surface free energy, microisland size geometry on the adsorption performances of L1210/leukocytes pairs are discussed.
\end{abstract}

(c) 2013 Elsevier B.V. All rights reserved.

\section{Introduction}

Cell-polymer surface interactions which are important for disease treatment or design of biomedical products are not well understood at present. These interactions were related to five parameters such as type and percent distribution of the chemical groups on the surface [1], surface roughness [1-5], surface wettability [6-8], surface free energy (SFE) of the substrate [6,9], and size and shape of the cell used for testing $[10,11]$. The distance between surface patterns and focal adhesion clusters on the cell membrane is also an important parameter for the cell to form a strong adhesion on a substrate $[1-3,12,13]$. Shapes, functions and viability of the cells may change as a result of their interaction with a patterned substrate [14]. Chemical composition and morphology of a substrate are important parameters affecting the adsorption of proteins present on the cell surface and initial cell adhesion [15-17].

When blood contacts with a substrate, the adhesion properties of normal blood cells (i.e. leukocytes, platelets) change depending on the surface properties of the substrate $[18,19]$. The substrate is quickly covered with proteins present in the serum. Differences in topography, chemical composition, charge and wettability in the substrate surface result in changes in type, conformation and

\footnotetext{
* Corresponding author. Tel.: +90 262605 2114; fax: +90 2626052105 .

E-mail addresses: yerbil@gyte.edu.tr, yerbil19@yahoo.co.uk (H.Y. Erbil).
}

amount of the adsorbed proteins. Protein adsorption is a dynamic process and proteins do not stay on the surface permanently, and over time the higher-affinity proteins replace the previously preadsorbed lower-affinity proteins [20]. Protein adsorption increases with the increase in hydrophobicity of the substrate since water molecules in the serum interact weakly with the surface enabling more proteins to adsorb. On the other hand, protein adsorption also increases with the increase in the surface roughness due to the increase of the total surface area. At the end, composition and conformation of proteins are different on the surface depending on the hydrophobicity and roughness of the surface [20]. These variations in proteins are recognized by distinct cell adhesion molecules; hence, cell adhesion is highly dependent on cell type. Every cell has a different combination of adhesion molecules expressed on their surface. For example, leukocytes are well endowed with integrin adhesion receptors [21]. Moreover, cancer cells are known to alter their adhesion molecules in order to invade and metastasize [22-25]. Therefore, it will be possible to allow a desired cell type to attach to a substrate by changing surface topography, composition, and wettability. Our aim is to design a polymer surface which allows L1210 adhesion and inhibit healthy leukocyte attachment. This selectivity is expected to be a result of the fact that surface receptors of healthy leukocytes and L1210 cancer cells might be different.

L1210 mouse lymphocytic leukemia cells are one of the model cell types used in cancer studies. The adhesion properties of L1210 
leukemia cells to solids have been examined previously and it was found that they do not adhere to glass whereas they easily bind to embryonic fibroblast monolayers [26]. It was also determined that adhesion of L1210 cells increased linearly with the increase of the sulfo group $\left(-\mathrm{SO}_{3} \mathrm{H}\right)$ concentration on sulfonated PS surfaces [27]. Adhesion properties of human leukocytes to surfaces were also investigated previously and it was found that the number of leukocytes which adhered to the polymeric surfaces modified by surface sulfonation or addition of other functional groups was higher than the non-modified surfaces [28]. The activation of adherent leukocytes was found to be dependent on surface topography, pattern geometry and surface chemistry of the substrate [18]. Davidson et al. showed that interaction of the normal cells with the topographically patterned surfaces was different from that of the cancer cells and plasma membranes of the normal cells were not easily deformed when the contact area between surface and cells was increased [4]. Yan et al. suggested that cell binding locations and properties can be controlled by designing specific micropattern sizes [29]. These findings show that micropatterned surfaces may be used in selective adsorption of different cell types.

Polymeric materials are widely used as biomedical materials. Surface patterning of polymers has been performed by applying several approaches such as lithography, UV light sensible photoresist, and use of specially synthesized polymers [30]. Most of these patterning methods are time consuming and expensive; however, Erbil et al. have demonstrated that a cheap commercial polymer such as polypropylene can be converted to a superhydrophobic surface by using solvent-nonsolvent phase separation process and this method can also be applied to large area surfaces and threedimensional materials [31]. Polymer blends which are the physical mixtures of the independent polymers can preferably be used for this purpose because blending may provide optimization of the desired properties of the final surface [32]. Solvent evaporation rate, phase separation, solvent diffusion, and SFE of the polymers have substantial effects on surface morphology of the polymer blends [31,33-35]. Micropatterned surfaces can also be prepared using polymer blends $[36,37]$. Kajiyama and co-workers observed that PMMA formed cylindrical micropatterns with controllable diameters by creating crests on the PS structures using spin-coating with PMMA/PS blends [38]. Overney et al. obtained micropatterned surfaces by performing annealing process through formation of PS monolayers by spin-coating on poly-ethylene-co-propylene film [39].

Whitesides and co-workers were the first to use micropatterned surfaces in the biomedical field in 1997 [12] and determined that human cells die on solids with particular patterns whereas they remain alive on solids with different patterns and concluded that cell size and shape are important factors for this cellular behavior $[2,12]$. The interactions between microstructured surfaces and cells have been intensively investigated in the last decades and it was found that cells strongly respond to topographic changes on surfaces [40-42]. The amount and/or orientation of the initial protein adsorption on topographically reconstructed surfaces occur differently from the flat surfaces [41].

In this study, we prepared flat, rough and micropatterned surfaces on round glass slides using commercial polymers such as polystyrene (PS), high density polyethylene (HDPE), polyethylene-polypropylene copolymer (PPPE), ethylene-vinyl acetate copolymer (EVA), and polyvinyl alcohol (PVOH) and also polymer blends (PS/HDPE, PS/PPPE) by dip coating method. We determined the specific surfaces where selective adsorption of L1210 leukemia cells occurs but human leukocytes do not adsorb. These surfaces may be used during blood exchange transfusion of leukemia patients to remove the cancerous cells (like L1210 leukemia cell) out of blood. The effectiveness of the parameters such as surface roughness, surface chemical groups and wettability onto surface/cell selective adsorption was also studied. Smooth polymer surfaces were prepared to observe the effect of roughness. It was found that selective adsorption performance changed depending on the diameters of short cylindrical islands and separation distance between the islands on the polymer surfaces especially when PS/PPPE polymer blend surfaces were used where island diameters can be easily controlled.

\section{Materials and methods}

\subsection{Materials}

PVOH (Merck, $\left.\quad M_{\mathrm{w}}=160,000\right), \quad$ PS (Sigma-Aldrich, $\mathrm{M}_{\mathrm{W}}=350,000$ ), HDPE (Basell Inc., HOSTALEN-GM8255, $\left.\mathrm{M}_{\mathrm{W}}>1,000,000\right)$, PPPE copolymer containing 12\% PE content by weight (Dow Chemical Co., VERSIFY 2300), and EVA copolymer containing $12 \%$ vinyl acetate content by weight (Dupont, ELVAX $660)$ were used as received. These polymers were dissolved in THF (Merck), xylene and toluene solvents (Tekkim, Turkey) to prepare polymer solutions. Ethanol (EtOH, Merck) was used as non-solvent. Ultrapure water, diodomethane, formamide, $\alpha$-bromonaphthalene, and ethylene glycol (all from Merck) were used as contact angle drop liquids. Round glass slides (Thermo Scientific) with diameters of 13 and $15 \mathrm{~mm}$ were used as substrates. All biological materials used in this study are analytical grade and were purchased from Invitrogen and Sigma-Aldrich.

\subsection{Preparation of homo- and copolymer films}

PVOH was dissolved in water, PS and EVA in toluene, HDPE in xylene, PPPE in THF solvents at a constant concentration of $10 \mathrm{mg} / \mathrm{mL}$. EtOH was added to PS and PPPE polymer solutions prepared in THF solvent by $10 \%(\mathrm{v} / \mathrm{v})$. The withdrawal rate of the mechanical dipper was varied between $320-764 \mathrm{~mm} / \mathrm{min}$ at room temperature for $\mathrm{PVOH}$ and PS polymers, at $60^{\circ} \mathrm{C}$ for PPPE and EVA, and at $115^{\circ} \mathrm{C}$ for HDPE. Clean round glass slides was kept in the polymer solution for $1 \mathrm{~min}$ to reach thermal equilibrium, and then withdrawn with a constant speed. Polymer films were kept in a desiccator for 3-4 h and completely dried in a vacuum oven at $40^{\circ} \mathrm{C}$ overnight. PVOH film was dried under vacuum overnight, then was kept in glutaraldehyde solution for $2 \mathrm{~h}$ and then washed using distilled water and dried under vacuum at $50^{\circ} \mathrm{C}$ overnight to prepare cross-linked PVOH surfaces. Surface sulfonation was carried out by submerging PS samples in sulfuric acid (60 vol.\%) for $24 \mathrm{~h}$. Sulfonated PS surfaces (PS-sulfo) were rinsed in deionized water, and air-dried.

\subsection{Preparation of PS/HDPE and PS/PPPE blend films}

PS, HDPE and PPPE polymer stock solutions were prepared in xylene and THF solvents at $10 \mathrm{mg} / \mathrm{mL}$ concentration at $10^{\circ} \mathrm{C}$ below the boiling points of the solvents. PS/HDPE and PS/PPPE blend solutions were prepared by mixing the different compositions for a final concentration of $10 \mathrm{mg} / \mathrm{mL}$ and stirred mechanically for $2-3 \mathrm{~h}$ at $60^{\circ} \mathrm{C}$ to reach equilibrium when $\mathrm{THF} / \mathrm{xylene}$ mixture was used and $115^{\circ} \mathrm{C}$ when only xylene was used. EtOH was added dropwise into the blend solution. Dip coating of the round glass slides by blend polymers was carried out with a mechanical dipper at a removal speed of $320-784 \mathrm{~mm} / \mathrm{min}$. Coated polymer films on glass slides were kept in a desiccator for 3-4 h and completely dried in a vacuum oven at $40^{\circ} \mathrm{C}$ overnight. Thicknesses of the coatings were between 0.5 and $2.0 \mu \mathrm{m}$. Surface topography of rough polymer blends was examined by 3D profilometry (Nikon, Eclipse-LV100D Microscope) and environmental scanning electron microscopy (ESEM, Quanta 200 FEG). 


\subsection{Contact angle measurement}

Static contact angles under air were measured by using a KSVCAM 200 contact angle meter. Equilibrium contact angle values $\left(\theta_{\mathrm{e}}\right)$ were determined after the needle was removed from a $5 \mu \mathrm{L}$ droplet formed on the solid surface. In addition, we measured both advancing $\left(\theta_{\mathrm{adv}}\right)$ and receding $\left(\theta_{\mathrm{rec}}\right)$ water contact angles (WCA) on the sample surfaces by increasing the volume of the droplets from 3 to $8 \mu \mathrm{L}$ and decreasing from 8 to $4 \mu \mathrm{L}$ respectively through the needle by using the automatic dispenser while the needle was kept within the liquid droplet. $\theta_{\text {rec }}$ were also measured by drop evaporation method for better precision $[43,44]$.

\subsection{Cell culture and maintenance}

L1210 (ATCC ${ }^{\circledR}$ CCL-219) and human primary leukocytes were used for in vitro studies. Human primary leukocytes were isolated from whole blood with standard separation by density method using Histopaque (Sigma). L1210 cells were maintained in high glucose DMEM, $4 \mathrm{mM}$ L-glutamine, 1\% Penicillin-Streptomycin, 10\% horse serum in standard cell culture conditions $\left(37^{\circ} \mathrm{C}, 5 \% \mathrm{CO}_{2}\right.$, and $95 \%$ humidity). Human primary leukocytes were maintained in F12 medium supplemented with $2 \mathrm{mM}$ L-glutamine, $10 \%$ calf serum, and $1 \%$ Penicillin/Streptomycin in standard cell culture conditions.

\subsection{Adhesion of L1210 cells and leukocytes on polymer surfaces}

Polymer coated surfaces were sterilized under UV light before cell culture experiments. Prior to cell adhesion experiments, cells were incubated in serum free media containing $4 \mathrm{mg} / \mathrm{mL}$ BSA and $50 \mu \mathrm{g} / \mathrm{mL}$ cyclohexamide for $1 \mathrm{~h}$ in standard cell culture conditions. Polymer coated surfaces and bare surfaces that were used as control were placed in 24-well plates and cells were seeded on surfaces at densities of 15,000 cells $/ \mathrm{cm}^{2}$ for leukocytes and 45,000 cells $/ \mathrm{cm}^{2}$ for L1210 cells in serum-free media. Cells were incubated for $2 \mathrm{~h}$ before they were washed with HBSS (Hank's Balanced Salt Solution). Attached cells were stained with $1 \mu \mathrm{M}$ Calcein AM for $30 \mathrm{~min}$. Random photos were taken from each well and cells were counted using Image J.

\subsection{Cellular morphology studies of L1210 cells on polymer surfaces}

In order to visualize the actin cytoskeleton of L1210 cells on polymer coated surfaces, cells were seeded at a density of 25,000 cells $/ \mathrm{cm}^{2}$. After $48 \mathrm{~h}$ of incubation, they were fixed with $3.7 \%$ formaldehyde, permeabilized with $0.25 \%$ Triton-X and stained with TRITC conjugated phalloidin. The cells were visualized under an upright microscope (Zeiss Axio Scope). To analyze the morphologies of L1210 cells on substrates, cells were fixed in $2 \%$ gluteraldehyde solution and dehydrated in increasing alcohol concentrations, dried with critical point-dryer (Tourismis Autosamdri $\left.{ }^{\circledR}-815 \mathrm{~B}\right)$ and imaged with a scanning electron microscope (FEI Quanta 200 FEG).

\section{Results and discussion}

Codes of the surfaces prepared using PVOH, PS, sulfonatedPS, HDPE homopolymers, PPPE and EVA copolymers and PS/PPPE, PS/HDPE polymer blends are shown in Tables 1-3.

\subsection{Surface characterization of flat polymer films and adhesion of L1210 cells and leukocytes on these surfaces}

PVOH, PS and PS-sulfo homopolymer surfaces were found to be nearly flat after examining their SEM images where no visible protrusions can be seen even at 40,000× magnification (Fig. 1a). PVOH and PS-sulfo surfaces were found to be hydrophilic, whereas PS surface was hydrophobic as seen in WCA results (Table 1). Contact angle hysteresis (CAH) results were varied between $12-32 \pm 1^{\circ}$. Surface sulfonation of PS resulted in nearly 2-fold increase in $\mathrm{CAH}$ indicating a high increase in the chemical heterogeneity on PS-sulfo surface. SFE values were calculated using $\theta_{\mathrm{e}}$ values by applying van Oss-Chaudhury-Good method $[44,45]$ and were found to range between 34.8 and $52.5 \mathrm{~mJ} / \mathrm{m}^{2}$.

Adhesion of L1210 leukemia cells and healthy leukocytes onto flat homopolymer surfaces were tested independently and it was found that relative adhesion of both $\mathrm{L} 1210$ cells and leukocytes onto hydrophilic PVOH and PS-sulfo surfaces was high while their adhesion onto hydrophobic PS surface was low (Fig. S1 in the Supplementary Data). The increase of adhesion of healthy leukocytes with the decrease of surface hydrophobicity is in agreement with the literature $[6,7,28,46]$. Our results were also in agreement with a previous study where adhesion performance of L1210 cells to the sulfonated PS surface was higher than that of non-sulfonated ones [27]. Regarding to cell selectivity, only PVOH surface showed selectivity where adhesion of healthy leukocytes was higher than the adhesion of L1210 cells. However, this was opposite to our expectations where we targeted to prepare the surfaces on which L1210 cells bind more, whereas healthy leukocytes perform less adhesion. Very low positive selectivity fitting our purpose was obtained only on the flat PS-sulfo surface.

\subsection{Surface characterization of rough polymer films and adhesion of L1210 cells and leukocytes on these surfaces}

SEM images of the rough polymer surfaces (HDPE, PPPE and EVA) were given in Fig. 1a. The presence of large spherulites was observed on HDPE coating with diameters of 10-20 $\mu \mathrm{m}$, where some nanofibrillar structures having a dimension of less than $1 \mu \mathrm{m}$ were seen at the center (Fig. 1a). PPPE had a low surface roughness without any spherulite formation. EVA sample was flat and small protrusions of $1-3 \mu \mathrm{m}$ in diameter were dispersed across the whole surface. The order of the surface roughness $\left(R_{\mathrm{rms}}\right)$ of the samples was HDPE $>$ PPPE $>$ EVA (Table 1 ), which was consistent with our previous publication [47] although the surface preparation methods are not the same. $R_{\mathrm{rms}}$ of EVA, HDPE and PPPE were generally small. HDPE and PPPE surfaces were hydrophobic and EVA was hydrophilic and the higher the roughness, the higher the CAH results were obtained (Table 1). SFE values of HDPE, PPPE and EVA varied in a small range between 30.8 and $34.8 \mathrm{~mJ} / \mathrm{m}^{2}( \pm 12 \%$ from the mean).

Adhesion of both cell types onto rough surfaces was found to be relatively higher than that onto flat surfaces (Fig. S1). Adhesion of both leukocyte and L1210 cells was found to be highest on the PPPE surface. Since PPPE and HDPE had very close WCA, CAH and SFE values, this difference in cell adhesion performance may be due to the roughness variation or the presence of different pattern structures on PPPE surface rather than its hydrophobicity (Table 1). Positive adsorption selectivity was observed on all of the rough surfaces where adhesion performance of L1210 cells on HDPE and PPPE polymer surfaces was nearly twice the leukocytes. Chemically heterogeneous EVA and PPPE copolymer surfaces showed the highest cell adhesion performance in this group. This fact reveals that rough and chemically heterogeneous surfaces cause higher cell adhesion in accordance with some previous publications $[1-3,12,13,48]$. In summary, we obtained positive selective adsorption on rough and chemically heterogeneous surfaces when commercial polymers are used however the selectivity ratio of L1210/leukocyte was insufficient. Then, we decided to prepare heterogeneous surfaces having 
Table 1

Polymer type, water contact angle, surface free energy and $R_{\mathrm{rms}}$ roughness results on flat and rough polymer surfaces.

\begin{tabular}{|c|c|c|c|c|c|c|c|}
\hline \multirow[t]{2}{*}{ Sample code } & \multirow[t]{2}{*}{ Polymer type } & \multicolumn{4}{|c|}{ Contact angle $\left( \pm 1^{\circ}\right)$} & \multirow[t]{2}{*}{$\gamma \mathrm{TOT}\left(\mathrm{mJ} / \mathrm{m}^{2}\right)$} & \multirow[t]{2}{*}{$R$ (rms) } \\
\hline & & $\overline{\theta_{\mathrm{e}}}$ & $\theta_{\mathrm{adv}}$ & $\theta_{\text {rec }}$ & $\overline{\mathrm{CAH}}$ & & \\
\hline $\mathrm{PVOH}$ & PVOH (100\%) & 46 & 48 & 38 & 12 & 34.8 & N.A. \\
\hline PS & PS $(100 \%)$ & 93 & 96 & 79 & 17 & 40.6 & N.A. \\
\hline PS-sulfo & Sulfonated-PS & 55 & 57 & 23 & 32 & 52.5 & N.A. \\
\hline HDPE & HDPE (100\%) & 105 & 114 & 87 & 27 & 32.9 & 1.07 \\
\hline PPPE & PPPE (100\%) & 106 & 107 & 83 & 24 & 30.8 & 0.63 \\
\hline EVA & EVA-12 (100\%) & 85 & 94 & 81 & 13 & 34.8 & 0.28 \\
\hline $\mathrm{PS}_{50} / \mathrm{HDPE}_{50}$ & PS/HDPE (50:50) & 101 & 107 & 84 & 23 & N.A. & N.A. \\
\hline
\end{tabular}

Table 2

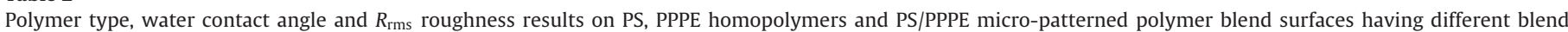
composition obtained by 10 vol.\% non-solvent (EtOH) addition.

\begin{tabular}{|c|c|c|c|c|c|c|}
\hline \multirow[t]{2}{*}{ Sample code } & \multirow[t]{2}{*}{ Polymer type } & \multicolumn{4}{|c|}{ Contact angle $\left( \pm 1^{\circ}\right)$} & \multirow[t]{2}{*}{$R$ (rms) } \\
\hline & & $\theta_{\mathrm{e}}$ & $\theta_{\mathrm{adv}}$ & $\theta_{\text {rec }}$ & $\mathrm{CAH}$ & \\
\hline$(\mathrm{PPPE})_{\mathrm{EtOH}-10}$ & PPPE (100\%) & 106 & 112 & 89 & 23 & N.A. \\
\hline$\left(\mathrm{PS}_{10} / \mathrm{PPPE}_{90}\right)_{\mathrm{EtOH}-10}$ & PS/PPPE (10:90) & 106 & 110 & 85 & 25 & 0.14 \\
\hline$\left(\mathrm{PS}_{20} / \mathrm{PPPE}_{80}\right) \mathrm{EtOH}_{-10}$ & PS/PPPE (20:80) & 105 & 111 & 81 & 30 & 0.15 \\
\hline$\left(\mathrm{PS}_{30} / \mathrm{PPPE}_{70}\right)_{\mathrm{EtOH}-10}$ & PS/PPPE (30:70) & 106 & 110 & 90 & 20 & 0.16 \\
\hline$\left(\mathrm{PS}_{50} / \mathrm{PPPE}_{50}\right)_{\mathrm{EtOH}-10}$ & PS/PPPE (50:50) & 106 & 109 & 88 & 21 & 0.18 \\
\hline$\left(\mathrm{PS}_{70} / \mathrm{PPPE}_{30}\right)_{\mathrm{EtOH}-10}$ & PS/PPPE (70:30) & 107 & 111 & 87 & 24 & 0.23 \\
\hline$(\mathrm{PS})_{\mathrm{EtOH}-10}$ & PS (100\%) & 100 & 101 & 87 & 13 & N.A. \\
\hline
\end{tabular}

specific pattern structures using polymer blends instead of using a single polymer.

\subsection{Surface characterization of micro-patterned $P S_{50} / H D P E_{50}$ polymer blend and its adhesion performance for L1210 cells and} leukocytes

We obtained $\mathrm{PS}_{50} / \mathrm{HDPE}_{50}$ blend surface which contains circular PS islands on it with diameters of 5-15 $\mu \mathrm{m}$ (Fig. 1a). Surface morphology of $\mathrm{PS}_{50} / \mathrm{HDPE}_{50}$ blend was similar to the reports given in the literature where the diameters of circular PS patterns were between 2 and $20 \mu \mathrm{m}$ depending on the synthesis conditions $[49,50]$. In general, the polymer with lower Mw and SFE concentrates on the surface to minimize the interfacial tension between polymer/air interface and thus HDPE usually covers the surface of PS. WCA and CAH results on the $\mathrm{PS}_{50} / \mathrm{HDPE}_{50}$ surface was found to be between PS and HDPE (Table 1).

Adhesion of L1210 cells was high on $\mathrm{PS}_{50} / \mathrm{HDPE}_{50}$ surface (Fig. S2a) however, the adhesion of healthy leukocytes on this blend surface decreased approximately 2-fold when compared with HDPE surface and the positive selectivity ratio of L1210 cells/leukocytes increased from 1.8 to 3.5 on $\mathrm{PS}_{50} / \mathrm{HDPE}_{50}$ (Fig. S2b). L1210 cells do not like to adhere to PS surfaces and they prefer to adhere onto HDPE regions however, the presence of circular PS islands increased the adhesion of L1210 cells more than that of a HDPE surface. Then, it is assumed that most of the blend surface was coated with HDPE including the top of the PS islands, probably with a very thin HDPE layer on them and the presence of these circular HDPE patterns caused the increase of the adhesion of L1210 cells and the decrease of leukocytes. Thus, the size and separation distance between circular PS islands are important factors affecting the adhesion of both cell types. Then we decided to synthesize new patterned surfaces having varying island diameters and separation distances.

\subsection{Surface characterization of micro-patterned PS/PPPE polymer blends films with varying blend composition and adhesion performance of L1210 cells and leukocytes on these surfaces}

Dissolution of HDPE in an organic solvent is a difficult process and we had to use xylene and heat up to high temperatures to prepare PS/HDPE blend solution. However, commercial PPPE copolymer may be used instead of HDPE and since PPPE can be easily dissolved in THF at $60^{\circ} \mathrm{C}$. Then, we prepared PS/PPPE polymer blends in THF by varying the blend compositions as 10:90, 20:80, 30:70, 50:50 and 70:30 where we added a constant 10 vol.\% EtOH into the solution for better phase separation during dip coating. SEM images of these surfaces were given (Fig. 1b) and diameters of the circular PS microislands on PS/PPPE blends were found to be between 1 and $10 \mu \mathrm{m}$ and were less than the ones formed on PS/HDPE blend.

All WCA results of PS/PPPE blends were very close to each other and also close to the WCA of PPPE surface obtained by 10 vol.\% EtOH addition to its THF solution (Table 2) indicating that WCA's were not affected by the presence of circular PS islands. This may be due to the complete coverage of circular PS islands by PPPE during film formation and these blend surfaces may be assumed to have a

Table 3

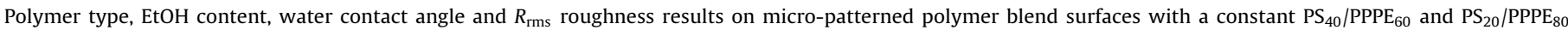
compositions where different vol.\% non-solvent (EtOH) was added.

\begin{tabular}{|c|c|c|c|c|c|c|c|}
\hline \multirow[t]{2}{*}{ Sample code } & \multirow[t]{2}{*}{ Polymer type } & \multirow[t]{2}{*}{ EtOH (vol.\%) } & \multicolumn{4}{|c|}{ Contact angle $\left( \pm 1^{\circ}\right)$} & \multirow[t]{2}{*}{$R(\mathrm{rms})$} \\
\hline & & & $\theta_{\mathrm{e}}$ & $\theta_{\mathrm{adv}}$ & $\theta_{\text {rec }}$ & $\mathrm{CAH}$ & \\
\hline$\left(\mathrm{PS}_{40} / \mathrm{PPPE}_{60}\right)_{\mathrm{EtOH}-4}$ & PS/PPPE (40:60) & 4 & 105 & 110 & 92 & 18 & 0.22 \\
\hline$\left(\mathrm{PS}_{40} / \mathrm{PPPE}_{60}\right)_{\mathrm{EtOH}-10}$ & PS/PPPE (40:60) & 10 & 105 & 111 & 87 & 24 & 1.54 \\
\hline$\left(\mathrm{PS}_{40} / \mathrm{PPPE}_{60}\right)_{\mathrm{EtOH}-14}$ & PS/PPPE (40:60) & 14 & 105 & 112 & 86 & 26 & 0.27 \\
\hline$\left(\mathrm{PS}_{40} / \mathrm{PPPE}_{60}\right)_{\mathrm{EtOH}-18}$ & PS/PPPE (40:60) & 18 & 106 & 112 & 84 & 28 & 0.14 \\
\hline$\left(\mathrm{PS}_{20} / \mathrm{PPPE}_{80}\right)_{\mathrm{EtOH}-6}$ & PS/PPPE (20:80) & 6 & 105 & 112 & 86 & 26 & 0.16 \\
\hline$\left(\mathrm{PS}_{20} / \mathrm{PPPE}_{80}\right)_{\mathrm{EtOH}-10}$ & PS/PPPE (20:80) & 10 & 105 & 111 & 81 & 30 & 0.15 \\
\hline$\left(\mathrm{PS}_{20} / \mathrm{PPPE}_{80}\right)_{\mathrm{EtOH}-14}$ & PS/PPPE (20:80) & 14 & 106 & 111 & 80 & 31 & 0.14 \\
\hline
\end{tabular}


a)
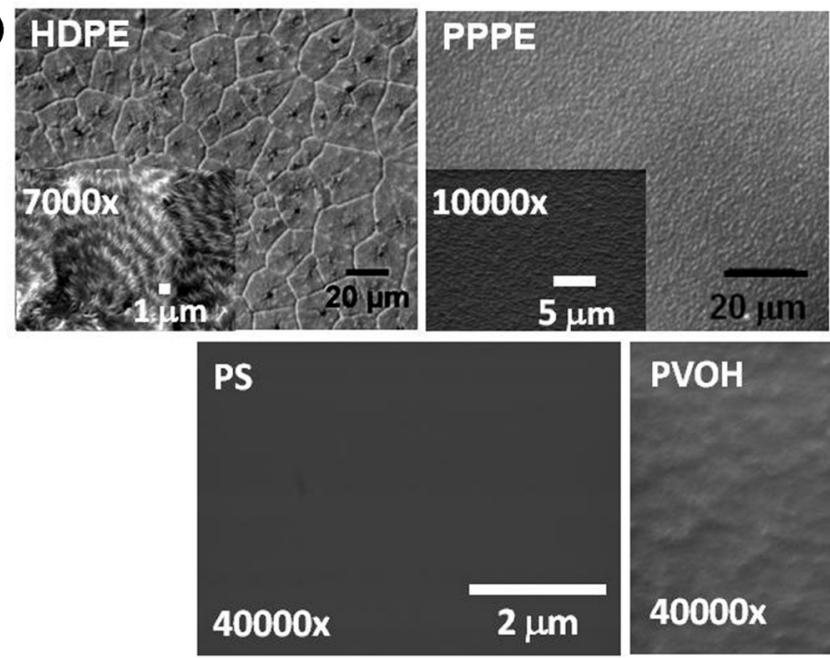
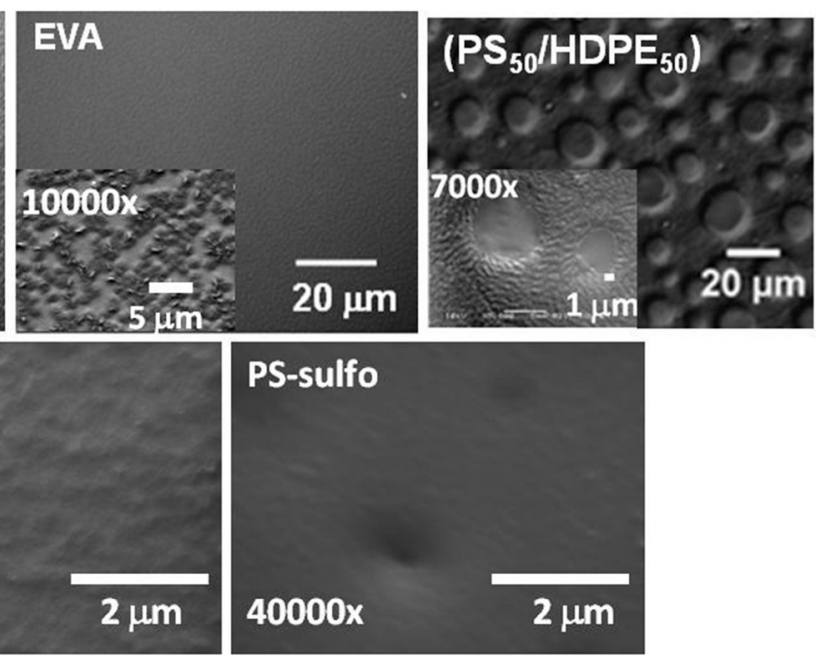

b)
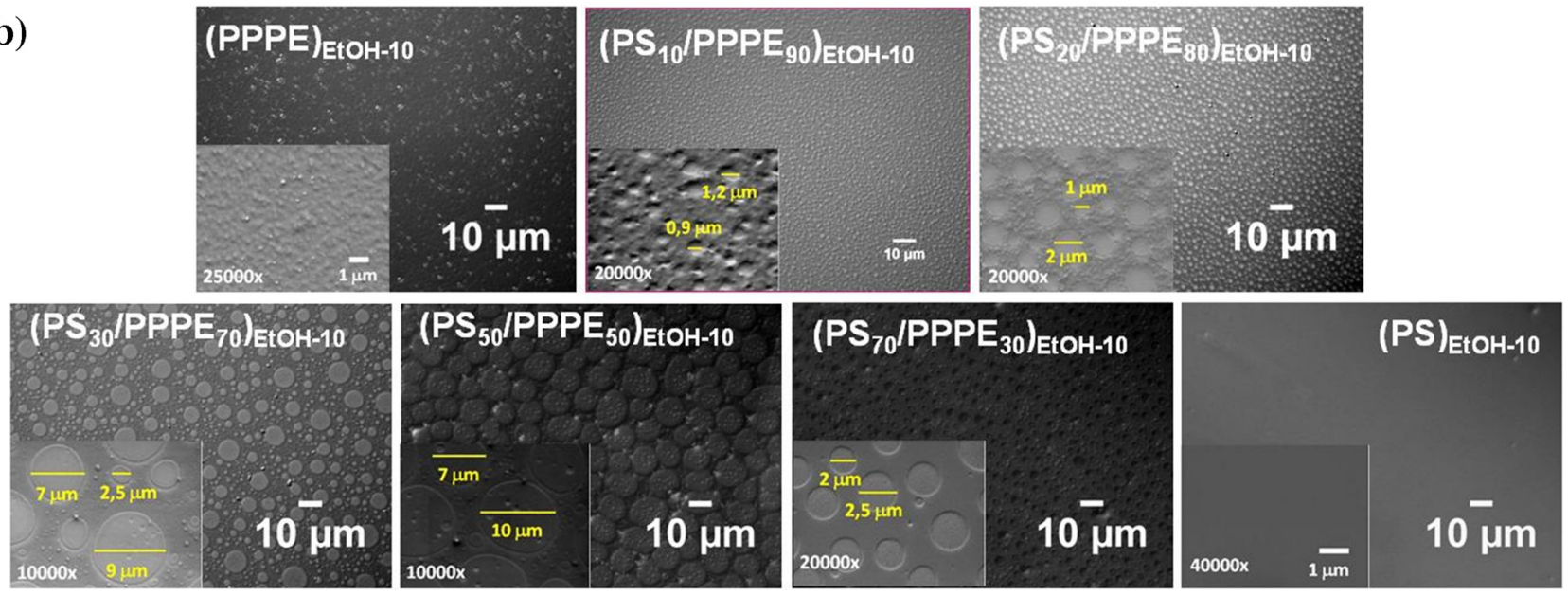

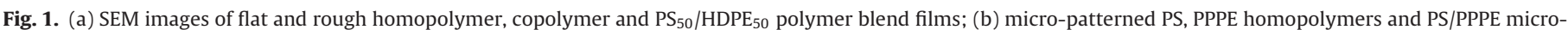
patterned polymer blend surfaces having different blend composition obtained by the addition of 10 vol.\% non-solvent (EtOH) to THF solution.

complete PPPE upper layer where the surface roughness and micropatterning were imposed by circular PS islands. This is reasonable because SFE of PPPE was $30.8 \mathrm{~mJ} / \mathrm{m}^{2}$ and much less than SFE of PS of $40.6 \mathrm{~mJ} / \mathrm{m}^{2}$ (Table 1) and PPPE having the lower SFE may prefer to concentrate on PS/air interface. It was found that the diameters of the circular PS islands on the surface can be controlled by changing the ratio of PS/PPPE blend while 10 vol.\% EtOH was added where PS diameters increased from 1 to $10 \mu \mathrm{m}$ with the increase of PS component in the blend up to $50 \%$ and then decreased down to 2-4 $\mu \mathrm{m}$ above $50 \%$.

L1210 cell adhesion increased on PS/PPPE blend surfaces with the increase of the diameter of the circular PS islands whereas leukocytes adhesion were close to each other on these surfaces regardless of the size of PS islands (Fig. 2a). All of the PS/PPPE polymer blend surfaces showed positive selectivity toward L1210 cells in agreement with our objective. L1210/leukocyte selectivity ratio ranged between 2.0 and 9.5 on these blend surfaces (Fig. 2b). (PPPE) $)_{\mathrm{EtOH}-10}$ surface performed the highest positive selectivity and L1210 cells adhered to this surface 9.5 times greater than the healthy leukocytes. Main reason of this high selectivity ratio was the less adhesion of leukocytes. The most successful second surface was found to be $\left(\mathrm{PS}_{20} / \mathrm{PPPE}_{80}\right)_{\mathrm{EtOH}-10}$ which showed a 7.8 -fold positive selectivity. Both of these surfaces have small microislands which allow the adhesion of L1210 cells but prevents adhesion of leukocytes. The increase in size of circular PS islands caused an increase of the adhesion of both L1210 cells and leukocytes for $\left(\mathrm{PS}_{50} / \mathrm{PPPE}_{50}\right)_{\mathrm{EtOH}-10}$ sample. It is obvious that the surface morphology arising from phase separation has an important role on the cell/surface adhesion performance.

As given in the introduction section, when blood contacts with a substrate, the substrate is quickly covered with proteins present in the serum and differences in topography, chemical composition, and wettability in the substrate surface result in changes in type, conformation and amount of the adsorbed proteins [20]. When surface roughness increases, protein adsorption also increases due to the increase of the total surface area. Composition and conformation of proteins are different on the surface depending on the hydrophobicity and roughness of the surface. Every cell has a different combination of adhesion molecules expressed on their surface and the variations in proteins on the substrate are recognized by distinct cell adhesion molecules; hence, cell adhesion is highly dependent on cell type. Moreover, cancer cells are known to alter their adhesion molecules in order to invade and metastasize [22-25]. Thus, surface receptors of healthy leukocytes and L1210 cancer cells might be different and only a specific cell type is allowed to attach to a substrate surface having specific surface topography and composition. In our work, we can only report which cell type prefers to attach to which surface type depending on its morphology, roughness and hydrophobicity. 

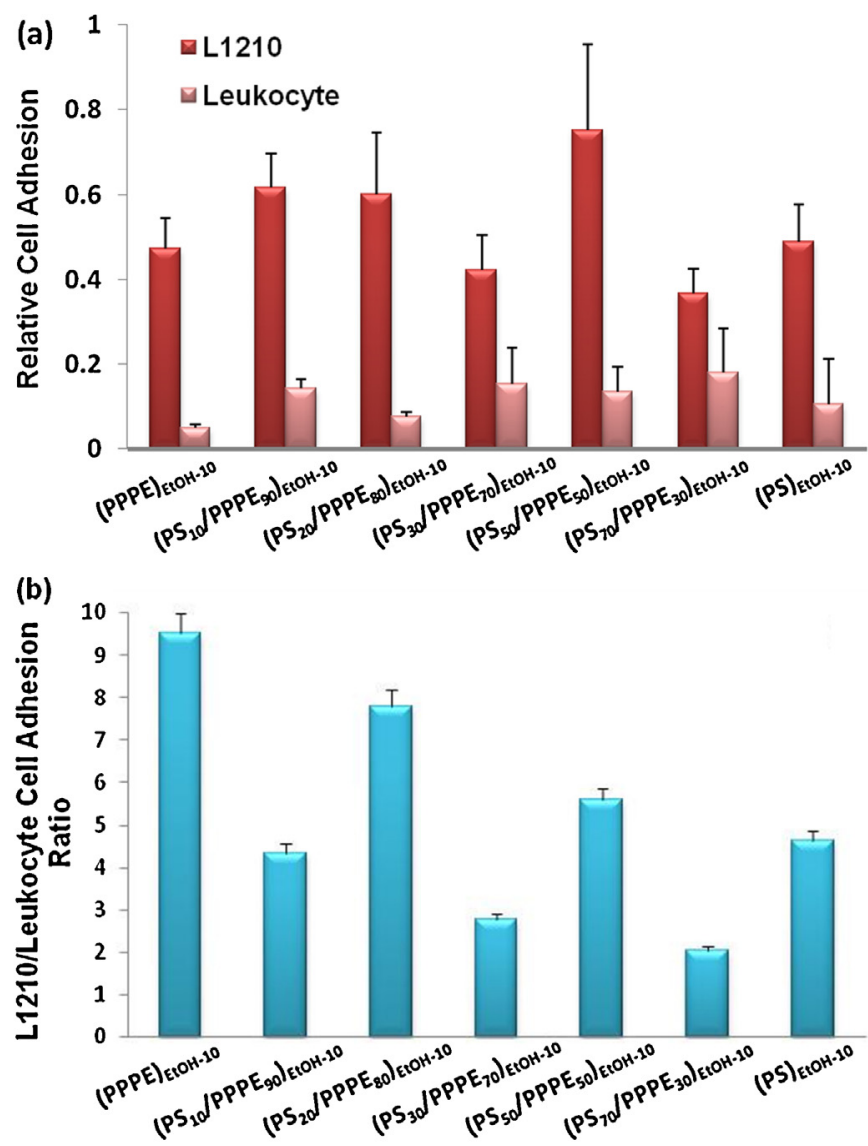

Fig. 2. (a) L1210 and leukocyte relative cell adhesion; (b) L1210/leukocyte cell adhesion ratio for micropatterned rough films prepared from PS/PPPE polymer blends with different blend compositions obtained by the addition of $10 \mathrm{vol} . \%$ non-solvent (EtOH) to THF solution.

\subsection{Effect of non-solvent addition: surface characterization of} micro-patterned $P S_{40} / P P P E_{60}$ and $P S_{20} / P P P E_{80}$ polymer blend films with varying non-solvent addition and adhesion performance of L1210 cells and leukocytes on these surfaces

Addition of non-solvent results in the variation of PS island sizes on the PS/PPPE blend surfaces. We prepared polymer blend

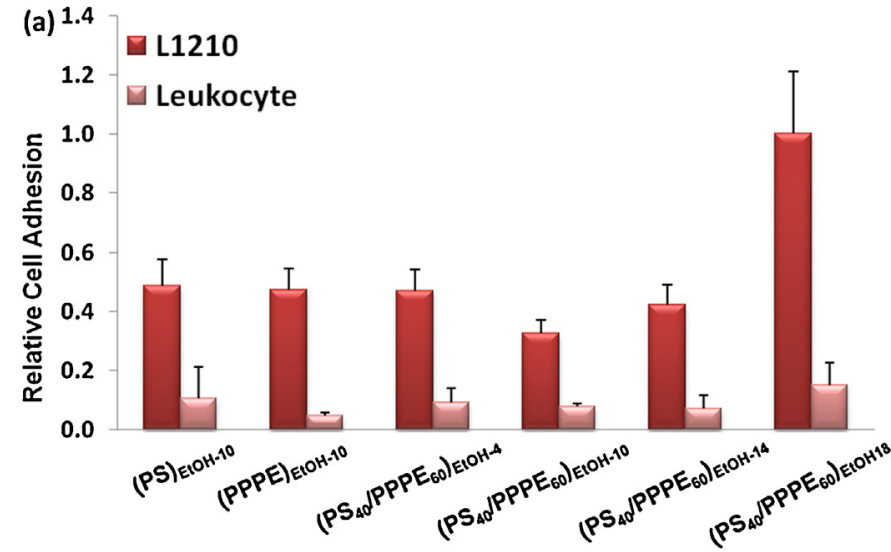

(b)

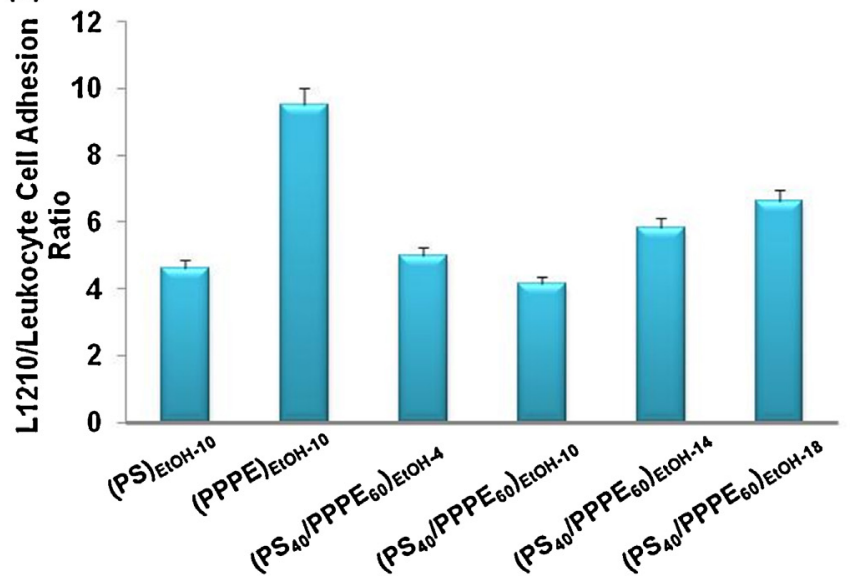

Fig. 4. (a) L1210 and leukocyte relative cell adhesion; (b) L1210/leukocyte cell adhesion ratio for micropatterned rough films prepared using constant $\mathrm{PS}_{40} / \mathrm{PPPE}_{60}$ blend composition and adding different vol.\% ethanol.

surfaces with a constant $\mathrm{PS}_{40} / \mathrm{PPPE}_{60}$ composition where different amounts of EtOH $(4,10,14$, and $18 \mathrm{vol} . \%)$ were added and WCA and $R_{\mathrm{rms}}$ results on these surfaces are shown in Table 3 . All the $\theta_{\mathrm{e}}$ and $\theta_{\text {adv }}$ values were very close to each other and also close to the value of PPPE copolymer as seen in this table, whereas $\theta_{\text {rec }}$ reduced and correspondingly CAH increased by the addition of EtOH which
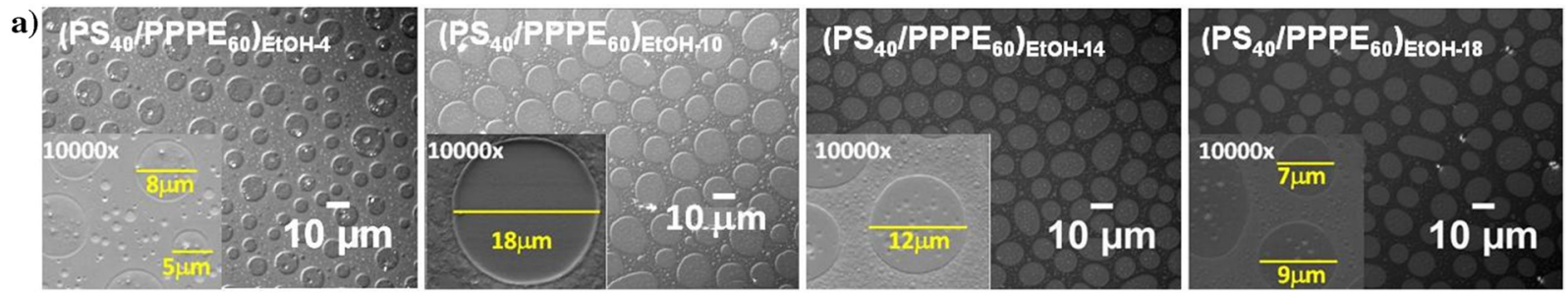

b)
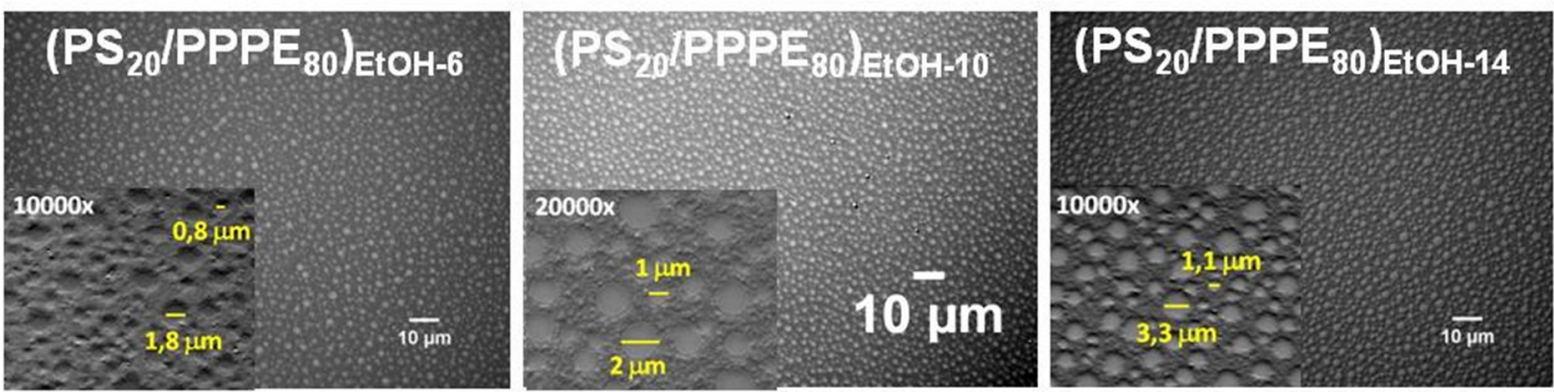

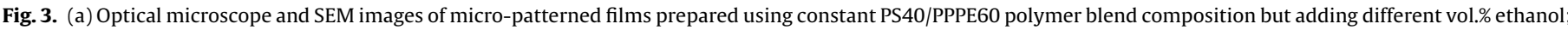
(b) micro patterned films prepared using constant $\mathrm{PS}_{20} / \mathrm{PPPE}_{80}$ polymer blend composition by adding different vol.\% ethanol. 
a)
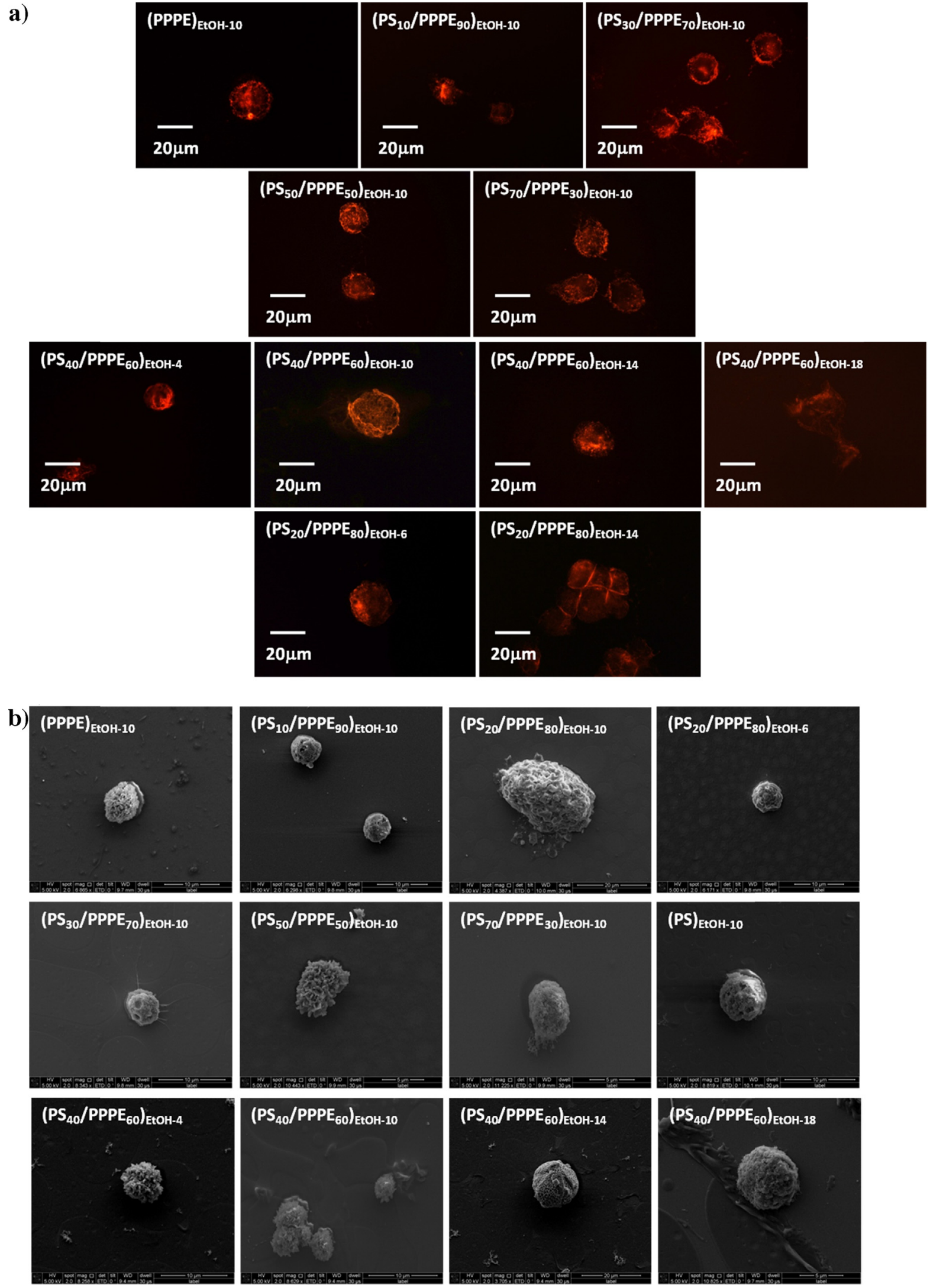

Fig. 5. (a) SEM images of L1210 cells; (b) actin staining of L1210 cells by phalloidin. Red: actin fibers. (For interpretation of the references to color in this figure legend, the reader is referred to the web version of this article.) 
increased the roughness and heterogeneity of the surface during phase separation. Diameters of circular PS islands were found in a range of 5-18 $\mu \mathrm{m}$ (Fig. 3a) and initially increased with the added EtOH amount, however then stayed approximately constant after 10 vol.\%.

Results of cell adhesions of L1210 cells and leukocytes onto the blend surfaces with a constant $\mathrm{PS}_{40} / \mathrm{PPPE}_{60}$ composition, where different amounts of EtOH was added were compared with sin-

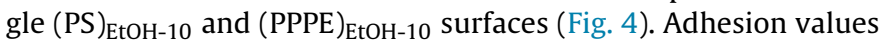
of L1210 cells were close to each other on these surfaces except $\left(\mathrm{PS}_{40} / \mathrm{PPPE}_{60}\right)_{\mathrm{EtOH}-18}$ surface (Fig. $4 \mathrm{a}$ ). All of the $\mathrm{PS}_{40} / \mathrm{PPPE}_{60}$ blend surfaces showed positive selectivity toward L1210 cells where ratio of L1210/leukocyte ranged between 4.2 and 6.0 on these blend surfaces (Fig. 4b). The highest selective adsorption was found on the $\left(\mathrm{PS}_{40} / \mathrm{PPPE}_{60}\right)_{\mathrm{EtOH}-18}$ surface where the separation distances between circular PS islands were slightly higher than other surfaces. $\theta_{\text {rec }}$ value for PPPE was found to be $83^{\circ}$ (Table 1 ) and this value was very close to that of $\left(\mathrm{PS}_{40} / \mathrm{PPPE}_{60}\right)_{\mathrm{EtOH}-18}$ of $84^{\circ}$ (Table 3 ), indicating that PPPE copolymer coated the top of the PS microislands during film formation. Again, it was found that the size and geometry of microislands has an important role on the cell/surface adhesion performance.

The above work was repeated by preparing $\mathrm{PS}_{20} / \mathrm{PPPE}_{80}$ blends in order to see the effect of EtOH addition onto the sizes of PS microislands. Diameters of circular PS microislands decreased due to the increase of the nucleation rate with the use of EtOH and varied between 0.5 and $4.0 \mu \mathrm{m}$ (Fig. $3 \mathrm{~b}$ ). The largest PS microislands were seen on $\left(\mathrm{PS}_{20} / \mathrm{PPPE}_{80}\right)_{\mathrm{EtOH}-14}$ surface. WCA and $R_{\mathrm{rms}}$ roughness results on micro-patterned polymer blend surfaces with a constant $\mathrm{PS}_{20} / \mathrm{PPPE}_{80}$ composition where different amounts of EtOH $(6,10$, and 14 vol.\%) were added are also shown in Table 3. Similar to the results presented above for $\mathrm{PS}_{40} / \mathrm{PPPE}_{60}$ blends, $\theta_{\mathrm{e}}$ and $\theta_{\text {adv }}$ values of the $\mathrm{PS}_{20} / \mathrm{PPPE}_{80}$ blends were very close to each other and also close to the value of PPPE (Table 3 ) whereas $\theta_{\text {rec }}$ value reduced considerably and correspondingly $\mathrm{CAH}$ value increased by the addition of EtOH.

Relative cell adhesion of L1210 cells and leukocytes to the blend surfaces having a constant $\mathrm{PS}_{20} / \mathrm{PPPE}_{80}$ composition with different amounts of ethanol addition was determined (Fig. S3). Positive selectivity toward $\mathrm{L} 1210$ cells was seen on all of the $\mathrm{PS}_{20} / \mathrm{PPPE}_{80}$ blend surfaces. Relative adhesion values of L1210 cells increased linearly with the increase of EtOH addition, however the adhesion of leukocytes were close to each other on these surfaces (Fig. S3a). This trend is similar to the increase of L1210 cell adhesion with the increase of EtOH addition (right side of Fig. 4a). Positive selectivity ratio of L1210/leukocyte ranged between 5.0 and 8.0 on these blend surfaces (Fig. S3b). The highest selective adsorption was found on $\left(\mathrm{PS}_{20} / \mathrm{PPPE}_{80}\right)_{\mathrm{EtOH}-14}$ surface. The increase of the circular PS diameter from 1 to $3.5 \mu \mathrm{m}$ with the increase of nonsolvent addition provided a positive effect on increasing adhesion tendency of L1210 cells.

\subsection{Characterization of $L 1210$ cell morphologies}

Upon binding to a substrate cells start to synthesize extracellular matrix proteins. Long term adhesion behaviors of cells, which determine the morphologies and organization of actin cytoskeletons of cells, depend on the interaction of surface bound proteins and cells [51]. In order to investigate the actin cytoskeleton of L1210 cells, they were stained with phalloidin to display F-actin organization (Fig. 5a). L1210 cells displayed actin cytoskeleton on all surfaces after $48 \mathrm{~h}$. SEM analyses were also performed to investigate compatibility of the surfaces to the cells in more detail. These analyses demonstrated that L1210 cells maintained their morphology over all surfaces (Fig. 5b). The morphological studies have shown that cells gained their expected morphologies at the end of $48 \mathrm{~h}$ and maintained their natural cytoskeletal organization. These experiments show that synthesized polymer thin films are biocompatible surfaces for cell studies. Diameters of L1210 cells used in this study were approximately $5 \mu \mathrm{m}$ (Fig. 5a) and the average diameter of a leukocyte is $10 \mu \mathrm{m}$ [52]. Thus, the enhanced adhesion tendency of leukocytes than L1210 cells on PPPE/PS polymer blend surfaces with small micro-pattern diameter might be caused by the size difference between these cell types.

\section{Conclusions}

We prepared polymer blend surfaces by dip coating onto glass where microislands were formed on the surface by phase separation. Our intention was to adsorb L1210 leukemia cells selectively much more than that of the healthy human leukocytes on these specific surfaces which were made of commercial polymers. We determined the surface properties and relative adhesion performance of the cells on these surfaces. It was found that the control on the diameters of circular PS microislands on the surface is possible especially when PS/PPPE blends are prepared using THF as solvent and EtOH as non-solvent. The top of the PS microislands was coated with a thin layer of PPPE having a lower SFE than that of PS during film formation. These surfaces were tested for their effect on cell viability through MTT tests. It was found that all of the PS/PPPE blend surfaces showed considerable positive selectivity toward L1210 cells. The increase in the amount of EtOH increased both the diameters of PS microislands and relative adhesion of L1210 cells on these surfaces. However, healthy leukocytes did not show this trend and their relative adhesion values were close to each other. Positive selectivity of L1210 cells/healthy leukocytes ratio approached to 9-fold in vitro. The surfaces showing the highest L1210/leukocyte selectivity ratio were (PPPE) $)_{\text {EtOH-10, }}\left(\mathrm{PS}_{20} / \mathrm{PPPE}_{80}\right)_{\mathrm{EtOH}-10}$ and $\left(\mathrm{PS}_{20} / \mathrm{PPPE}_{80}\right)_{\mathrm{EtOH}-14}$. The diameter of circular PS micro-islands on these successful surfaces varied between 1.0 and $3.3 \mu \mathrm{m}$. It was also shown that the sizes of circular micro-islands on the surface have an important role on the $\mathrm{L} 1210$ cell/surface adhesion performance. It is possible that the conformation and amount of the adsorbed serum proteins on these specific blend surfaces are different depending on the size of micro-islands and the variations in proteins on the substrate are recognized by distinct cell adhesion molecules depending on the type of the cell. Thus, L1210 leukemia cells or healthy leukocytes showed different adsorption behavior on these surfaces. These findings may be used to develop new treatment options for people with leukemia with suitable scale-up.

\section{Acknowledgement}

The authors gratefully acknowledge the support from The Scientific and Technological Research Council of Turkey (TUBITAK) under the project "Synthesis and use of micro/nano patterned chemically heterogeneous surfaces for the selective adsorption of L1210 leukemia cells" (Project No: MAG-110M181).

\section{Appendix A. Supplementary data}

Supplementary material related to this article can be found, in the online version, at http://dx.doi.org/10.1016/j.colsurfb. 2013.09.040.

\section{References}

[1] E.M. Blanco, M.A. Horton, P. Mesquida, Langmuir 24 (2008) 2284-2287.

[2] G.M. Whitesides, E. Ostuni, S. Takayama, X.Y. Jiang, D.E. Ingber, Annu. Rev. Biomed. Eng. 3 (2001) 335-373. 
[3] Y. Xie, T. Sproule, Y. Li, H. Powell, J.J. Lannutti, D.A. Kniss, J. Biomed. Mater. Res. 61 (2002) 234-245.

[4] P.M. Davidson, H. Ozcelik, V. Hasirci, G. Reiter, K. Anselme, Adv. Mater. 21 (2009) 3586-3590.

[5] M. Nikkhah, F. Edalat, S. Manoucheri, A. Khademhosseini, Biomaterials 33 (2012) 5230-5246.

[6] M. Lampin, R. Warocquier-Clerout, C. Legris, M. Degrange, M.F. Sigot-Luizard, J. Biomed. Mater. Res. 36 (1997) 99-108.

[7] M.C. Lensen, V.A. Schulte, J. Salber, M. Diez, F. Menges, M. Möller, Pure Appl. Chem. 80 (2008) 2479-2487.

[8] Y. Arima, H. Iwata, Biomaterials 28 (2007) 3074-3082.

[9] H.M. Kowalczynska, Colloids Surf. B: Biointerfaces 4 (1995) 137-149.

[10] C.W. Evans, Cell Biol. Int. Rep. 16 (1992) 1-10.

[11] A.N. Efremov, E. Stanganello, A. Welle, S. Scholpp, P.A. Levkin, Biomaterials 34 (2013) 1757-1763.

[12] C.S. Chen, M. Mrksich, S. Huang, G.M. Whitesides, D.E. Ingber, Science 276 (1997) 1425-1428.

[13] Y.C. Wang, C.C. Ho, FASEB J. 18 (2004) 525-527.

[14] M.J. Dalby, N. Gadegaard, R.S. Tare, A. Andar, M.O. Riehle, P. Herzyk, C.D.W. Wilkinson, R.O.C. Oreffo, Nat. Mater. 6 (2007) 997-1003.

[15] A.S.G. Curtis, J.V. Forrester, P. Clark, J. Cell Sci. 86 (1986) 9-24.

[16] H.J. Busscher, I. Stokroos, J.G. Golverdingen, J.M. Schakenraad, Cells Mater. 1 (1991) 243-249.

[17] B.G. Keselowsky, D.M. Collard, A. Garcia, J. Biomater. 25 (2004) 5947-5954.

[18] J. Tan, W.M. Saltzman, Biomaterials 23 (2002) 3215-3225.

[19] J. Folkman, A. Moscona, Nature 273 (1978) 345-349.

[20] D.A. Puleo, R. Bizios (Eds.), Biological Interactions on Materials Surfaces Understanding and Controlling Protein, Cell, and Tissue Responses, Springer, Dordrecht, 2009.

[21] M. Stewart, M. Thiel, N. Hogg, Curr. Opin. Cell Biol. 7 (1995) 690-696

[22] N. Makrilia, A. Kollias, L. Manolopoulos, K. Syrigos, Cancer Invest. 27 (2009) 1023-1037.

[23] J.S. Desgrosellier, D.A. Cheresh, Nat. Rev. Cancer 10 (2010) 9-22.

[24] H.M. Kowalczynska, M. Nowak-Wyrzykowska, J. Dobkowski, R. Kolos, J. Kaminski, A. Makowska-Cynka, E. Marciniak, J. Biomed. Mater. Res. 61 (2002) 260-269.

[25] A. Stachurska, J. Elbanowski, H.M. Kowalczynska, Cell Biol. Int. 36 (2012) 883-892.

[26] B. Wojciak, W. Korohoda, J. Cell Sci. 97 (1990) 433-438.
[27] H.M. Kowalczynska, M. Inkielman, M. Nowak-Wyrzykowska, L. Stolowska, J. Doroszewski, Colloids Surf. B: Biointerfaces 30 (2003) 193-206.

[28] A. Bruil, J. Terlingen, T. Beugeling, W. Vanaken, J. Feijen, Biomaterials 13 (1992) 915-923.

[29] C. Yan, J. Sun, J. Ding, Biomaterials 32 (2011) 3931-3938.

[30] J.P. Spatz, A. Roescher, M. Moller, Adv. Mater. 8 (1996) 337-340.

[31] H.Y. Erbil, A.L. Demirel, Y. Avci, O. Mert, Science 299 (2003) 1377-1380.

[32] D.R. Paul, J.W. Barlow, J. Macromol. Sci. Part C: Polym. Rev. 18 (1980) $109-168$.

[33] I.O. Ucar, M.D. Doganci, C.E. Cansoy, H.Y. Erbil, I. Avramova, S. Suzer, Appl. Surf. Sci. 257 (2011) 9587-9594.

[34] M.D. Doganci, C.E. Cansoy, I.O. Ucar, H.Y. Erbil, E. Mielczarski, J.A. Mielczarski, J. Appl. Polym. Sci. 124 (2012) 2100-2109.

[35] S.K. Kumar, T.P. Russell, Macromolecules 24 (1991) 3816-3820.

[36] M. Khayet, A.M. Vazquez, K.C. Khulbe, T. Matsuura, Surf. Sci. 601 (2007) 885-895.

[37] S. Walheim, M. Boltau, J. Mlynek, G. Krausch, U. Steiner, Macromolecules 30 (1997) 4995-5003.

[38] K. Tanaka, A. Takahara, T. Kajiyama, Macromolecules 29 (1996) 3232-3239.

[39] R.M. Overney, D.P. Leta, L.J. Fetters, Y. Liu, M.H. Rafailovich, J. Sokolov, J. Vac. Sci. Technol. 14 (1996) 1276-1279.

[40] A.S. de Leon, J. Rodriguez-Hernandez, A.L. Cortajaren, Biomaterials 34 (2013) 1453-1460.

[41] E.T. den Braber, J.E. de Ruijter, L.A. Ginsel, A.F. von Recum, J.A.J. Jansen, Biomed. Mater. Res. 40 (1998) 291-300.

[42] T.G. van Kooten, A.F. von Recum, Tissue Eng. 5 (1999) 223-240.

[43] H.Y. Erbil, G. McHale, S.M. Rowan, M.I. Newton, Langmuir 15 (1999) 7378-7385.

[44] H.Y. Erbil, Surface Chemistry of Solid and Liquid Interfaces, Blackwell Publishing, Oxford, 2006.

[45] C.J. van Oss, M.K. Chaudhury, R.J. Good, Chem. Rev. 88 (1988) 927-941.

[46] A. Bruil, L.M. Brenneisen, J.G.A. Terlingen, T. Beugeling, W.G.V. Aken, J. Feijen, J. Colloid Interface Sci. 165 (1994) 72-81.

[47] I.O. Ucar, C.E. Cansoy, H.Y. Erbil, M.E. Pettitt, M.E. Callow, J.A. Callow, Biointerphases 5 (2010) 75-84.

[48] V.A. Tegoulia, S.L. Cooper, J. Biomed. Mater. Res. 50 (2000) 291-301.

[49] J.K. Lee, C.D. Han, Polymer 40 (1999) 6277-6296.

[50] N. Virgilio, C. Marc-Aurele, B.D. Favis, Macromolecules 42 (2009) 3405-3416.

[51] K. Anselme, Biomaterials 27 (2006) 1187-1199.

[52] S.B. McKenzie, Clinical Laboratory Hematology, Prentice Hall, New Jersey, 2004. 